\title{
A JOGÁLLAMISÁG FOGALMÁNAK TEORETIKAI PROBLÉMÁI AZ EURÓPAI UNIÓ JOGFELFOGÁSÁNAK VONATKOZÁSÁBAN
}

\author{
Theoretical Problems of the Rule of Law in Relation to the Legal \\ Conception of the European Union
}

\section{Hegedős Soma ${ }^{1}$}

\begin{abstract}
Absztrakt: A jogállamiság kérdése az utóbbi időkben vált különösen vitatott témává Európában. A jog és az államhatalom viszonyának kérdése valójában már olyan ókori klasszikusok vizsgálódásának tárgya is volt, mint Platón és Arisztotelész. A modern közgondolkodásban a kontinentális „Rechtsstaat” és az angolszász „Rule of Law” teóriák ugyan különböző értelmezési lehetôségeket jelentenek, mindazonáltal újabb álláspontok szerint ez a két koncepció lényegében ugyanazon az elvi felfogáson alapszik. Ugyan az Európai Unió tagállamainak eltérőek a jogi és alkotmányos hagyományai, ez a különbség mindezidáig azonban nem került kihangsúlyozásra az uniós jogban. Az Európai Unió jogállamiságról alkotott felfogása expanzív jellegư: egyre több teoretikai és gyakorlati követelményt vonnak be értelmezési tartományába. Egyes kritikai álláspontok szerint mindazonáltal éppen maga az Európai Unió intézményrendszere sem képes megfelelni a Rule of Law és a Rechtsstaat koncepciók bizonyos kritériumainak.
\end{abstract}

Kulcsszavak: Európai Unió, jogállamiság, joguralom, tagállami szuverenitás, uniós jog

Abstract: The Rule of Law theory has lately become one of the most controversial topics in Europe. The relationship between the law and the power had already been in the focus of such classical ancient philosophers like Plato and Aristotle. The modern application of the continental

${ }^{1}$ Dr. Hegedős Soma (Nemzetközi Közszolgálati Egyetem, Danube Institute) kutató. E-mail címe: somahegedos@gmail.com

A szerző további munkásságát lásd a Magyar Tudományos Művek Tára oldalán: https: $/ / \mathrm{m} 2 . \mathrm{mtmt}$.hu/gui2 $/$ ?type $=$ authors\&mode $=$ browse\&sel $=10039745$ 
„Rechtssaat” and its Anglo-Saxon counterpart, the „Rule of Law” theories represent different ways of implementations and alternative domains of understandings. According to the latest opinions these two concepts were actually built on the same fundamental principles. Though the EU member states have different backgrounds of legal and constitutional history, this difference has not yet been emphasized by the Union. Understanding of the Rule of Law in the EU has an expansive nature: it defines more and more theoretical and practical expectations in the name of this concept. But according to some critics, it is the European Union itself that proves incapable of meeting some expectations and criteria of the Rule of Law and the Rechtsstaat theories.

Keywords: Rechtsstaat, rule of law, European Union, national soveregnity, European Union law

\section{BEVEZETÉS}

A jogállamiság kérdése az elmúlt évek egyik forró témájává vált Európában. A jelenség érdekessége, hogy a jogállamiság immár nem kizárólag jogelméleti diskurzusok, sokkal inkább politikai viták tárgya. Ezt mutatja világosan az a körülmény is, hogy a viták fókuszpontjában kevésbé a jogállamiság pontos mibenléte, rendszerszintű érvényesíthetőségének korlátai, hanem sok esetben inkább a korrupció, egyes nemzetállami kormányzatok politikai irányvonala, valamint bizonyos sajátos politikaiideológiai elképzelések nemzetállami szintű érvényesítése áll. ${ }^{2}$

Jelen áttekintő elemzésünkben azokról a fogalmi keretekről és teoretikai álláspontokról kívánunk áttekintő képet adni, amely által az Európai Unió jogrendje és a jogállamiság intézményének érvényesíthetősége közötti feszültség is érthetőbbé válik. Vizsgálódásunk kiindulópontjául mindenekelőtt magának az Európai Unió és a jogállamiság mibenlétének fogalmi feltárása szolgál. Az elemzés második részében az Európai Unió

2 Erre szolgálnak szemléltetésként a korábban Romániát, legutóbb Magyarországot és Lengyelországot bíráló jogállami biztos, Vera Jourová körül kialakult politikai viharok. Amíg például Magyarország jobboldali konzervatív miniszterelnöke, Orbán Viktor lemondásra szólította fel Jourovát egyes kijelentései miatt, addig számos baloldali politikus, így például az Osztrák Szociáldemokrata Párthoz tartozó Bettina Vollath, a német Zöldek által az Európai Parlamentbe delegált Sergey Lagodinsky támogatásáról biztosította Jourovát. Forrás: SIEBENBAHR, 2020. 
szisztematikájának a jogállami kritériumok szempontjából megfogalmazott egyes kritikus pontjaival foglalkozunk, érintve a szuverenitás és a demokrácia témaköreit is.

Bevezetésként elsődlegesen az Európai Unió ún. „sui generis” karakterével, jogi és politikai felépítményének sajátos fejlődési pályájával szükséges foglalkozni. Az akadémiai definíciók alapján az Európai Unió napjainkra, német kifejezéssel élve ún. „Staatenverbund”-dá vált. Ennek a német műszónak nemcsak a magyar, hanem lényegében az angol, vagy a francia szaknyelvben sincs pontos megfelelője, így magyarázatra szorul. A szövetségi szintű német alkotmánybíróság 2009-es kulcsfontosságú ítélete szerint az Európai Unió egy Staatenverbund, vagyis „szuverénként megmaradó államok egy olyan szűk, tartós kapcsolata, amely szerződéses alapokon közhatalmat gyakorol, s amelynek alaprendje mindazonáltal a tagállamok rendelkezési jogának alárendelt, valamint amelyben a tagállamok népei - vagyis a tagállamokhoz tartozó polgárok - a demokratikus legitimáció alanyai maradnak." - mondta ki ezt az ún. Lisszaboni ítélet, amelynek a tagállamok vonatkozásában is fontos megállapítást tett. ${ }^{3}$ Eszerint a tagállamok a Lisszaboni Szerződés alapján továbbra is az alapszerződése urai (német kifejezéssel: Herren der Verträge), így pedig szuverének és a nemzetközi jog önálló jogalanyai maradnak, ilyen minőségük alapján pedig nem vonható el tôlük az a jog, hogy az integrációs folyamatot a megállapodások fényében folyamatosan felülvizsgálhassák. Ennek fényében pedig az EU ,alkotmányos rendje”, az Unióra vonatkozó nemzetközi szerződések és a primer jogforrások pusztán származékos - levezetett jogrendet képeznek. Ennek rögzítése azért is bír kulcsjelentőséggel, mert valójában már az 1990-es években, majd a 2000-es években is lényegében közpolitikai témává vált, hogy az Unió úton van abba az irányba, hogy „szuperállammá”, vagy legalábbis valamiféle alkotmányközösséggé (német kifejezéssel: Verfassungsverbund) váljon. Már utóbbinak is nagy jelentősége van a jogállamiság mint alkotmányos érték szempontjából, így annak is, hogy az Európai Unió a Lisszaboni Szerződés alapján - jelentősrészt éppen a fenti Lisszaboni ítélet korlátozó jellegú megállapításainak következtében megmaradt valahol a Staatenverbund és a Verfassungsverbund között félúton. Kérdésként vetődik fel persze, hogy hogyan juthat el egyáltalán alig fél évszázad alatt egy „szén-, és acélközösség” az integráció ilyen szoros fokaira. Erre válasszal egyrészről természetesen a tagállamok által megkötött

32 BVE 2/08, 229-334. 
alapszerződések szolgálnak, másrészről - és ennek is hasonló jelentősége van a jogállamiság szempontjából, amelyre később még utalni fogunk - az Európai Unió Bíróságának ún. jogteremtő tevékenysége. Ez azt jelenti, hogy az uniós jog, egyáltalán az Európai Unió működési mechanizmusa szempontjából olyan alapvetô jelentőségú megállapítások, mint hogy például az Unió szupranacionális szervezet, amelynek jogi aktusai a tagállamok polgáraira nézve közvetlenül is joghatást válthatnak ki, illetôleg, hogy az Európai Unió joga önálló jogrendet alkot, amelyet a nemzetállami bíróságoknak is alkalmazni kell. Utóbbit lényegében az Európai Unió Bíróságának olyan ítéletei mondták ki, mint az ún. Van Gend and Loos és a Costa/ENEL ügyekben született határozatok. ${ }^{4}$

Mindezeket a fogalmakat az alábbiakban következő teoretikai álláspontokkal való ütköztetés miatt volt szükséges tisztázni.

\section{A JOGÁlLAMI GONDOLKODÁS KEZDETEI}

Ami a jogállamiságot illeti, nem pusztán a jogállamiság lényegéről, hanem egyáltalán már a jogállami gondolat megjelenésérôl kialakított álláspontok között is releváns különbségek húzódnak. Egyes nézetek szerint ugyanis a jogállamiság lényegével egyező felfogások valójában már az antikvitásban, vagyis messze az alkotmányosság, egyáltalán a modern jog kialakulását megelőzően megjelentek. Martyn Krygier szerint ez a jogállamiság lényegével egyező felfogás lényegében az az egyszerű gondolat volt, hogy a jog ne pusztán szolgálja a (köz)hatalmat, hanem vállaljon részt annak gyakorlásában és egyúttal korlátozásában is. ${ }^{5}$ Való igaz, hogy a jog hatalomhoz képest alárendelt szerepének vitatása már Platónnal is feltúnik: „Az az állam, amelyben a törvény alá van rendelve az uralkodók önkényének (...), szerintem bukásra van ítélve, amelyben azonban ezzel szemben a törvény az uralkodók felett áll és azok a törvény szolgái, ott én mindenütt jólétet látok." " Arisztotelész Platónnál is többet foglalkozott a hatalom, az államformák és a jog kapcsolatával, s ugyancsak hangsúlyozta a jog tekintélyének és szupremáciájának jelentőségét. „Az ember tökéletesedve minden más élőlénynél nemesebb, elszakadva a jogtól (nomos) és a törvénytől (dikế) azonban valamennyi közül a legrosszabb."’ Fontos

\footnotetext{
${ }^{4}$ C-36/63 és C-6/64

${ }^{5}$ CZARNOTA - KRYGIER - SADURSKI, 2006. 265.o.

${ }^{6}$ SUSEMIHL, 1882. 69.o.

7 ARISZTOTELÉSZ, 2014. 48.o.
} 
azonban hangsúlyozni, hogy Arisztotelész képes volt érzékelni magának a jognak is bizonyos határait és problémáit, így például, hogy nem mindegy, mi annak tartalma. „(...) a legfőbb államhatalom a törvényeket (nomos) kell, hogy megillesse, feltéve, ha azok jól vannak megalkotva." ${ }^{\circ}$ Később a keresztény társadalomfilozófiában Aquinói Szent Tamás munkásságát is összekötik már a modern jogállamiság gondolatával újabb tanulmányok. Aquinói egy közpolitikai tárgyú írásában értekezett arról, hogy a királyra ugyanúgy vonatkoznak az állami törvények, mint bárki másra: aki másra vonatkozóan törvényt hoz, az köteles azokat a törvényeket saját magára nézve is kötelező erejűnek tekinteni, vélte Aquinói.

Ehelyütt összegzésként csak annyit tehát, hogy legalábbis egyes közgondolkodóknál már az ókortól megjelent az a felfogás, mégha csak elvontan is, hogy a politikai szférát jogi előírások által felállított keretek közé kell szorítani, illetôleg a hatalmi tekintély működését sem lehet kivonni teljesen az állami törvények hatálya alól. A jogállamiság modern intézményének eszmei kibontakozása mindazonáltal csak a XIX. századra tehető, jogtörténetileg pedig mindenekelőtt a porosz állami gyakorlattal, valamint az angolszász common law jogfejlődésével hozható párhuzamba.

\subsection{A Rechtsstaat - típusú jogállam és alapproblémái}

A német Rechtsstaat - típusú jogállami gondolkodás kezdeteit klasszikusan a XVIII. század végi kontinentális jog- és államfejlődéssel szokás összekötni, elsődlegesen a korabeli Poroszország és Ausztria államjogi gyakorlatában lejátszódó fejleményekkel. A XVIII. században a kontinensen a jogi gondolkodás számos területén új - a jogállami felfogással már párhuzamba állítható - elképzelések jelentek meg, elegendő Cesare Beccaria 1764-ben megjelenő Dei delitti e della pena (magyar címén „A bűnökről és a büntetésekről”') címû híres művére gondolni, amelyet később Ritter von Feuerbach a rendkívül nagy jelentőségű „,nullum crimen sine lege” („nincs bűncselekmény bűntető törvény nélkül”) elvek megfogalmazásával vitt tovább büntetójogi területen. Természetesen ezeknek a gondolatoknak is megvoltak az eszmei előzményeik, Beccaria művével kapcsolatban például Christian Thomasius, Grotius és Thomas Hobbes hatása is kimutatható. ${ }^{10}$ Az ún. felvilágosult abszolutizmus korszakában mind a két német államban

\footnotetext{
8 ARISZTOTELÉSZ, 2014. 153.o.

${ }^{9}$ SVARTZ, 2010. 148.o.

10 Villata, 2016. 18-20.o.
} 
olyan jogállami tendenciák indultak el, amelyek a közjog világán kívül a magánjogra is hosszútávú hatást gyakoroltak. A fejlemények elsősorban a Poroszországban 1794-ben kibocsátott Allgemeines Landrecht nevű államjogi tárgyú törvényi szabályozással, továbbá egy bizonyos Carl Gottlieb Svarez nevű jogász tevékenységével köthetôk össze, aki központi szerepet játszott az igazságügyi reformok előkészítésében. Svarez alapgondolata az volt, hogy szükség van jogi előírásokra és elvekre, amelyek kötik magát a törvényhozót is és képesek ezáltal hosszabb távon is szolgálni a polgári szabadság biztosítását. Svarez tehát a jogállami gondolatot egy tartalmi értékkel, a polgári - és nem politikai - szabadsággal kötötte össze. ${ }^{11}$ Miközben évtizedekkel korábban Poroszország politikai felépítését még leginkább az jellemezte, hogy a legkülönfélébb igazgatási területek felett katonai biztosok felügyeltek, a XVIII. század közepétől jelentős változások kezdtek el lejátszódni az állami gyakorlatban. Dilthey megfogalmazása szerint a porosz jogállami fejlődés három viszonylag tisztán elkülöníthető szakaszra bontható fel: Az első stádium volt az abszolutisztikus felépítésű állam stádiuma, amelyben a monarcha a hatalom korlátlan birtokosa volt, törvényeket bocsáthatott ki és bírói döntéseket hozhatott. A második szakasz volt a törvényileg szabályozott állam, amelyben az uralkodó kötve van bizonyos törvényekhez, amelyeket az általa önálló organizmusként felállított bírói testületek vizsgálnak felül. A harmadik fejlődési szakasz az alkotmányos állam szakasza, amelyben a néptudat és a törvények tartalmi azonosságát egy ugyancsak önálló testületként felállított törvényalkotói szerv biztosítja. Dilthey úgy látta, hogy Poroszországban a Landrecht, vagyis a civil jogot, a büntetőjogot és a közjogot is egységesen kodifikáló államjogi szabályozás jelentette az abszolutisztikustól a jogállami felé való átmenetet. ${ }^{12}$ A Landrecht ráadásul már a Preambulumában tartalmazta a jogállamiság legáltalánosabb elveit: „Ezek a törvények az állam valamennyi tagját kötik társadalmi pozíció, rang és nemi különbségekre való tekintet nélkül.”; „Az állam valamennyi lakója - személye és vagyona védelme érdekében - ugyanarra a védelemre jogosult." "13

A XIX. századra a kontinentális jogfelfogásban a jogállamiságnak három értelmezési iránya alakult ki, részben az abszolút monarchiához való viszony alapján: elméleti szempontból megkülönböztethető egy tartalmi, egy intézményi és egy ún. formális Rechtsstaat-felfogás. A tartalmira - materiális

\footnotetext{
11 CONRAD, 1961. 9-10.o.

12 Dilthey, 1985. 200.o.

13 Allgemeines LandreCHT, 1794., 22. és 77. cikk
} 
jogállamiságra - szolgált példaként Svarez, vagy Mohl, előbbi a jogállamiság fontos tartalmi pontjának találta például a polgári szabadságot. Mohl továbbvitte ezt a gondolatot, ő úgy találta, hogy a szabadságjogok mellett a hatalmi ágak megosztásának is fontos szerepe van a jogállami múködésben. ${ }^{14} \mathrm{~A}$ jogállamiság intézményi érvényesítése elsődlegesen a bírói szervezet függetlenségét, illetőleg az államigazgatás bírósági kontrolljának kiépítését célozta meg. Ennek volt kiemelkedő képviselője Rudolf von Gneist, porosz jogász és politikus, aki ugyan bizonyos politikai törekvéseit tekintve még antidemokratikusnak is volt nevezhető, azonban Angliában szerzett tapasztalatai alapján úgy tartotta, hogy a társadalmi-politikai stabilitásnak fontos biztosítékai a bírósági fórumok. ${ }^{15}$ Végül a harmadik kategória a formális jogállamiság, amelynek a (poszt)modern jogi gondolkodók inkább negatív jelentéskört tulajdonítanak, mivel nem határozott meg tartalmi jellegú jogállami kritériumokat. A formális jogállamiságértelmezés nem feltételez egy olyan magasabb rangú normát, amelyhez a törvényhozásnak folytonosan tartania kell magát. Ennek jelentősége napjainkban például a nemzetközi emberi jogi egyezmények és a nemzetállami szuverenitás feszültsége kapcsán van. A formális jogállami értelmezésre klasszikusan Friedrich Julius Stahlt szokták felidézni, mégha valamennyire vitatott is, hogy Stahl valóban teljes mellszélességgel a puszta formális jogállamiság mellett foglalt-e állást. Stahl mindazonáltal írásművében hangsúlyozta, hogy a jogállamiság „egyáltalán nem az állam célját és tartalmát" kell, hogy meghatározza, pusztán az állami múködés „módját és karakterét”, vagyis azt, hogy hogyan valósítsa meg az állami célokat. ${ }^{16}$

Kis jog-, illetőleg államelméleti kitérővel érthetô meg jobban a Rechtsstaat-típusú jogállamiságra vonatkozó felfogások közötti különbség: annak, hogy éppen a formális, vagy materiális jogállami koncepció érvényesítéséről van-e szó, nagy jelentősége van, amelyre már a XX. században - éppen a II. világháborút megelőzően és Adolf Hitler hatalomra kerülésével nagyjából egyidejűleg - Hans Kelsen is rámutatott, mégha jogfelfogása később - különösen a II. világháborút és a német nemzetiszocialista kormányzat rémtetteit követően - erősen vitatottá is vált. Kelsen értelmezése szerint az állam és a jog lényegében azonos entitás, minden állam egy önálló jogrendet alkot, ilyen értelemben pedig lényegében egy

\footnotetext{
${ }^{14}$ MOHL, 1829. 267.o.

${ }^{15}$ HAHN, 1977. 1366.o.o

16 STAHL, 1878. 138.o.
} 
despotikus állam is ,jogállam”. „Ha az állam és a jog azonossága világossá válik, akkor lesz érthetô az is (...), hogy lényegében lehetetlen az államot a joggal igazolni. Pontosan, ahogy a jogot sem lehetséges joggal igazolni, hacsak a jog alatt egyszer a „pozitív”, másszor a „helyes” jogot, vagyis az igazságosságot értjük. És pont így bizonyul helytelennek az államnak a jogállamisággal való legitimálási kísérlete - mivel minden állam egyúttal egy jogállam is." - írja Kelsen. ${ }^{17}$ Kelsen szerint az a felfogás, amely a jogállamiságot bizonyos tartalmi kritériumokkal, mint szabadságjogok, törvényszerűség, stb. tölti fel, lényegében egy „természetjogi előítélet” a jogállamiságról. Kelsen pozitivista jogelmélete szerint a jog és az állam megkülönböztetésének egyik legalapvetőbb indoka valójában nem tudományelméleti, sokkal inkább ideológiai. Mivel az állam (hatalom) fennállásának metafizikai igazolása sok esetben eredménytelen, ezért válik a jog az állam (hatalom) fontos eszközévé, hogy a jog eszközével igazolhassa saját magát és erősíthesse tekintélyét. „Így lesz az állam az erőszak egyszerű tényszerűségéből jogállam.” - jegyzi meg Kelsen. ${ }^{18}$

A hatalom, az erôszak és a jog feszültségteljes összefüggéseire már Kelsent megelőzően is, még a XIX. században egy másik német jogtudós, Rudolf von Jhering is rámutatott vitatottá vált elméleteiben. Rudolf Jheringnél a jog kétféle módon jön létre, mindkét eset szoros összefüggésben áll az erőszakkal, az egoizmus - írja Jhering - a joghoz jut el kényszerítő ereje révén. „Az erőszak története a földön az emberi egoizmus története, az egoizmus története pedig abban áll, hogy az ember igyekszik elsajátítani, hogyan lehet az erôszakot úgy felhasználni, hogy az idegen erőket nemcsak pusztán ártalmatlanná, hanem maga számára hasznossá is tegye." - írja Jhering. ${ }^{19}$ A lényegibb verzió tehát az állam a hatalomnak, sôt annak az erőszaknak (német kifejezéssel: Gewalt) a kifejeződése, amely egy adott társadalmi viszonyrendszerben dominánssá válik. A jog pedig ebből ered, az „erősebb érdekéből”. Ez a jogállamiság szempontjából egy rendkívül lényeges álláspont Jheringtől. A jog az az eszköz, amelyen keresztül az erőszak számára előnyt hozó megfontolásokból önmagát korlátozva a legyőzöttekkel való kapcsolatát szabályozza oly módon, hogy velük az együttélés feltételeit illetően szerződik. Az erőszak tehát önmagát korlátozza, amelyet a felek betartanak. Az erőszak így elismer egy normát, aminek alá kívánja magát vetni, és az erőszak által elfogadott ezen norma a

\footnotetext{
${ }^{17}$ KELSEN, 2008. 135-136.o.

18 KELSEN, 2008. 126.o.

19 JHERING, 1884. 243.o.
} 
jog. Jheringnél az erőszak egyrészt a jogot létrehozó, s az az előtti, egyedül valóságosan létező lételméleti valóság, amelynek önszántából tett önkorlátozása a jog. Jhering rövid összefoglalása szerint tehát lényegében a jog nem más, mint az erôszak politizálása. ${ }^{20}$

Ehelyütt csak utalunk rá, hogy az erőszaknak és a jognak ilyen szoros összekapcsolása különösen a második világháború megrázkódtatásait követően vált rendkívül vitatottá és elvezetett az ún. „törvényes jogtalanság” természetjogi koncepciójáig. Eszerint az igazságosságnak és a jognak szükségszerűen kell, hogy legyen közös pontja, a jog nem hagyhatja teljesen figyelmen kívül az igazságosságot. Érdekességként megjegyzendő, hogy mindazonáltal éppen az igazságosság jegyében megindult német „Mauerscbützen” - eljárások lényegében éppen jogállami garanciákkal - így például a visszaható hatály tilalmával - kerültek ellentmondásos viszonyba az 1990-es években.

\subsection{A Rule of Law megjelenése}

A Rechtsstaat felfogással szokták párhuzamba állítani az angolszász eredetú 'rule of law' kifejezést, amely a common law típusú jogi gondolkodásban a jogállamiság (joguralom) kifejezője. A rule of law alapjainak eszmei lerakását elsődlegesen Albert Venn Dicey XIX. század munkásságával kötik össze, azonban a fogalom gondolatkörének etikai gyökerei egészen az 1215-ös Magna Chartáig is visszanyúlnak. „To no one will we sell, to no one deny or delay right or justice." - olvasható a Magna Chartában, amelyben már egyfajta jogelvként rögzítették az államjogi rendelkezések egységes és mindenkivel szemben egyenlő alkalmazásának ethoszát. ${ }^{21}$ A rule of law kifejezés első érdemi használata sem a jogelmélethez kötődik, hanem jogtörténeti vonatkozású, 1610-ben az alsóház, vagyis a House of Common I. Jánosnak címzett egy petíciót, amelyben az alsóház tagjai az alábbiak szerint fogalmaztak: „Egy sincs a között a sok-sok boldogság és szabadság között, amelyet a te alattvalóid felséged elődei - királyok és királynők - uralma alatt úgy élveztek volna és amelyet kedvesebbnek és drágábbnak tartottak volna, mint a jog uralmának biztosságát, amely kijelöli a fejnek és a tagoknak is, hogy milyen jogok illetik meg őket és amely nem szolgáltatja ki azokat a kormányzás önkényének és szeszélyeinek." ${ }^{22}$ Voltaképpen ez egy kezdőpontja is volt a

\footnotetext{
${ }^{20}$ JHERING, 1884. 242-259. o.

21 VON DER PFORDTEN, 2014. 23.o.

${ }^{22}$ HALLAM, 1827. 441.o.
} 
XVII. századi Angliában kibontakozó hatalmi küzdelmeknek, amelyeknek eredményeképpen a rule of law általános alkotmányos elvként konkrét állami jogszabályok formájában öltött testet, amelyek egyúttal a különböző társadalmi érdekcsoportok között létrejövő quasi politikai kiegyezést is visszatükröztek. Az uralkodói hatalom alkotmányos keretek közé való szorításának tendenciáját jelezte Samuel Rutherford Lex Rex címú munkája 1644-ben, amelyben - azon felül, hogy immáron ő is következetesen használta benne a ,joguralom” kifejezést - már magával a mú címével is sugallta a monarchia jogi keretek közé való beszorítását: az ismert latin regula „Rex lex” ugyanis lényegében a király primátusát jelezte, míg Rutherford Lex Rex kifejezése éppenhogy arra utalt, hogy a „lex” a királyt is szabályok közé szorítja. Rutherford a következőképpen fogalmaz a „rule of law” vonatkozásában: „A fejedelem ennélfogva fejedelem marad, társadalmi lény, férfi és király is, akinek adnia és vennie kell, ígérnie, szerződést kötnie és rendelkezéseket is kell hoznia: ezért ô immár nem „regula regulans”, hanem a jog uralma alatt áll.”’23 A polgárháborús küzdelmek végén előbb 1679-ben a Habeas Corpus, majd a Stuart dinasztia detronizálását követően a Bill of Rights és a Türelmi Törvény 1689-es elfogadásával került megalapozásra az alkotmányos parlamentáris monarchia egyensúlyi intézményrendszere, amelyek a rule of law eszmei alapján további törvényi garanciákat tartalmaztak.

Visszatérve még Dicey-hoz, Dicey munkásságát alapvetően határozta meg Austin fél évszázaddal korábbi szuverenitáselmélete, melyet a jogi és a politikai szuverenitás szétválasztásával Dicey tovább árnyalt. A jogalkotó hatalom ebben az értelmezésben akkor lehet szuverén, amennyiben jogi értelemben nem korlátozott, ellenben a politikai szuverenitásról abban az esetben lehet szó, ha a döntéshozó akarata a polgárok engedelmessége révén érvényesül, így kirajzolódik tehát a norma érvényessége és alkalmazása közötti releváns különbség. A jogi szuverenitás nyilvánvalóan a parlamenté, mint az állami jog (angol kifejezéssel: statute law) kiadmányozójáé, ez a jog ugyanakkor a common law mellett csak szubszidiárius szerepet játszik. Ugyanakkor a bíróságok az igazságosság és a jog uralmának jegyében mégis kontroll alatt tarthatják az érvényesülő jogot, egyrészt annak fényében, hogy a rule of law értelmében a törvénynek mindenki, még a szuverén is engedelmeskedni tartozik, másrészt azzal, hogy jogfejlesztő tevékenységük révén a joguralmi elvek érvényesülését garantálni tudják, melyeknek hála a

${ }^{23}$ RUTHERFORD, 2014. 236.o. 
személyekkel szembeni szabályszerű joghátrányok kizárólagos formáját a common law alapján lefolytatott bírósági eljárások képezhetik. ${ }^{24}$

\section{A JOGÁLLAMI GONDOLAT POLITIKAI ÖRÖKSÉGE ÉS AZ EURÓPAI INTEGRÁCIÓ}

Ezek voltak tehát a kontinentális - német és az angolszász típusú jogállami fejlődés főbb történeti - eszmei alapjai. Ehelyütt csak utalunk arra, hogy a jogállamiságról szóló vita két alapvető jelentőségű sarokpontja az, hogy a jogállamiság fogalmának különböző értelmezési módozatait ki lehete békíteni egymással, vagyis mennyiben azonosak, továbbá, hogy milyen viszonyban állnak az Európai Unió jogrendszerével.

$\mathrm{Az}$ első pont tekintetében eltérőek az álláspontok: vannak olyan nézetek, amelyek szerint bizonyos közös „eszmei magon” túl mérvadó és lényeges különbségek is fennállnak. „A „Recht”, vagyis a jog a Rechtsstaatkoncepcióban nem teljesen ekvivalens a rule of law „law”-típusú jogfelfogásával, és az államra, mint „Staat”-ra vonatkozó koncepció sem illik igazán jól bele az angol-amerikai jogi és politikai gondolkodás eszmei univerzumába." - írja ezt például Touri. ${ }^{25} \mathrm{Az}$ elmúlt évtizedekben javarészt a globalizmus és az európai integráció hatására jelentôsen megerősödni látszik azonban az a felfogás, amely szerint a jogállamiságra vonatkozó európai - különösen a fenti német és angolszász - koncepciók között lényegében nincs feloldhatatlan különbség, amely egy közös európai jogállami keretrendszer felállítását az Európai Unió tekintetében ellehetetlenítene. Amennyiben végigvesszük a jogállamiságról alkotott felfogásokat, úgy könnyen találhatjuk úgy, hogy ez az álláspont mégis vitathatónak tűnik. Rule of law, stato di diritto, Etat de droit, Rechtsstaat. Ezek bizonyos értelmezések szerint nem egyszerüen nyelvi fordítások, hanem kulturális megfelelők fellelései. Ennek alapján okkal vethető fel, hogy nehéz, sőt, talán lehetetlen, olyan egységes tartalmakat megfogalmazni, melyek minden tagállam „levizsgáztatása” szempontjából egységes kritériumként használhatók. Persze még mindig marad annak a lehetősége, ha az említett fogalmakat mint olyan formákat értjük, melyek a jog és az állam (politika) viszonyát írják le. Ez megkönnyíti az értékelést, de nem szünteti meg a problémát. Formális értelemben valószínúleg minden tagállam megfelelne a

\footnotetext{
${ }^{24}$ DICEY, 1923. 70-74.o.

25 TUORI, 2013. 14.o.
} 
kritériumoknak, következésképpen egy ilyen értékelésnek sok értelme nem lenne. Lényeges hangsúlyozni azonban, hogy az államoknak az önálló jogipolitikai kultúrához való joga mély összefüggésben áll a szuverenitás kérdéskörével. Miként évtizedekkel ezelőtt Hermann Lübbe német politikai filozófus éppen az európai népek sajátos identitása tekintetében mutatkozó különbségek miatt - elsősorban az önrendelkezés jogának szempontjából megközelítve - megfogalmazta: Európa kulturális sokféleségének történelmi öröksége nem teszi lehetővé politikailag az Európai Egyesült Államok létrehozatalát. ${ }^{26}$

Neil MacCormick összetettebben közelítette meg ezt a kérdést, szerinte a rule of law és a Rechtsstaat felfogások között nem áll fenn lényegi tartalmi különbség. Az, hogy a Rechsstaat fogalom utal az államra, míg a rule of law nem, pusztán az eltérő alkotmánytörténeti fejlődés következménye. Az amerikai-brit alkotmányjogban ugyanis az „állam” eleve problematikus fogalom, elkülönülten lényegében nem képezte a jogelméleti gondolkodás tárgyát. Az angolszász gondolkodásban az állam a „kormányzat”, a „korona”, vagy a „parlament”, hiszen ott a királyi uralkodó és a parlament között folyt a küzdelem a szuverenitásért. A parlament és az uralkodó között folyó hatalmi harcokban erôsödött fel a független common law jelentősége, amelyet a bírói fórumok biztosítottak. Ezzel szemben Poroszországban, illetőleg a német egységet követően a küzdelem azért folyt, hogy a politikai-hatalmi tekintélyt, előbb az uralkodót mint szuverént, majd az államot mint szuverént jogilag korlátozni lehessen. „Miközben a rule of law a kormányzati hatalom állítólagos visszaéléseivel szemben inkább egy ideális, a törvénynek fenntartott jogi formához kapcsolódik, a kormányzat hivatkozása a „rule of law”-ra, vagy másként a „law and order"-re legtöbbször azt célozza, hogy a demokratikus többség által megalkotott statutúmszerű jognak tiszteletet követeljen." - írja MacCormick. ${ }^{27}$ Ez a jogtörténeti eltérés érdekes helyzetet teremt: MacCormick úgy látja, hogy a Rechtsstaat-ot semmiképpen sem lehet szembe helyezni a rule of law-val, ez a két fogalom azonos alapelvet takar. Mindazonáltal az is igaz, hogy a két fogalom különböző ,,alkotmányos valóságokra” vonatkozik, így az a mód, ahogyan a jogállami - Rechtsstaat és rule of law szerinti - követelményeket realizálják egy adott államban, eltérő alkotmányos berendezkedésű országok esetén eltérő eredményekhez vezethet.

${ }^{26}$ LÜBBE, 1994. 57-68.o.

${ }^{27}$ MACCORMICK, 1984. 65-70.o. 
MacCormick egy másik tanulmányában amellett foglal állást, hogy korunkat a posztszuverenitás jellemzi. Az egysíkúan államközpontú vagy Európa-központú megközelítésekkel szemben újfajta szemléletet javasol, amelyben egyrészt a politikát és a jogot elválaszthatatlan összefonódásban látja, másrészt a jogrendszer fogalmát nem szúkíti le a szuverén állam által alkotott és kikényszerített jogra. Az 1648-ban megkötött vesztfáliai békeszerződést követôen a szuverén állam hatalma alaptétel lett, korunkban azonban hanyatlik a szuverenitás politikai-jogi eszméje, amit az Európai Unióban is láthatunk. A szuverenitás jogi értelemben a jogalkotás bármilyen jogi korlátozástól való mentessége. Politikai értelemben az a testület szuverén, vagy mindenekfelett álló, amely akaratának az állampolgárok feltétel nélkül alávetik magukat. Azokban az országokban, ahol alkotmányos tradíciók vannak, nehéz megállapítani, hogy ki a szuverén. MacCormick koncepciója szerint a jogállam, azaz a Rechtsstaat fogalmának meghatározásakor ki kell hagyni a politikai szuverenitás előzetes meglétét. Ez alapján a jogállam jogszabályok és normák intézményes rendszere, amely meghatározza a jogalanyok számára előírt kötelességeket és a jogi intézményekre ruházott törvényhozó, végrehajtó és bírói hatalmat. A Rechsstaat olyan jogrendszerrel rendelkező állam, amelyben ez a jogrendszer szabályozza és korlátozza a politikai tisztviselők és az állampolgárok irányítását, és így nem teszi lehetővé a jogrendszer melletti vagy feletti egységes politikai szuverenitás feltételezését. Ebben a rendszerben az alkotmányértelmezés elfogadott. Ez azt mutatja, hogy a szuverenitás nem, hogy nem szükséges, hanem nem is kívánatos az állam és a jog viszonyában. Egy megfelelően felépített alkotmányos állam nincs alávetve semmilyen törvény feletti szuverenitásnak. Mindazonáltal lényeges, hogy az Európai Bíróság 1964-es állásfoglalása szerint az európai közösség egy új jogrend megalkotására törekszik, amely nincs a tagállamok jogrendjének alárendelve, hanem mint egy külön, szuverén jogrendszer foglal helyet. Hozzátehetjük: MacCormick felfogása teoretikai szempontból izgalmas, ugyanakkor gyakorlati kivitelezhetősége megkérdőjelezhető, hiszen éppen a szuverenitás „schmitt-i megközelítésére” ${ }^{28}$ nem ad választ: vagyis arra, hogy ki lesz az, aki dönt. ${ }^{29}$

Az utóbbi évtizedekben megerősödött az a felfogás, hogy a jogállamiság követelményének ma már több különböző alkotmányos értéket

28 Carl Schmitt a jogállamisággal is szoros teoretikai összefüggésben alkotott híres megfogalmazása szerint ,,szuverén az, aki dönt”.

${ }^{29}$ MACCORMICK, 1999. 123-136.o. 
is magában kell foglalnia. Albrecht Weber szerint ma már egyfajta közös európai jogtradíciót jelent, hogy jogállami értéknek számít valamennyi hatalmi ág alkotmányos szintű szabályozása, egyúttal az alkotmány tekintélyének primátusa, az államigazgatás törvényszerű működése, az államigazgatásra vonatkozó jogi normák konkrét és egyértelmű megalkotása is. Ugyancsak ide tartozik a bírói hatalom törvényhez kötöttsége, a jogállami garanciák, a visszaható hatály tilalma és a jogbiztonság. Weber szerint a jogállamiság közös európai elve ma már egyértelműen „materiális”, ugyanis a Rechtsstaat, az Etat de droit és a rule of law egyaránt az emberi jogok, a szabadság és az egyenlőség értékeit kell, hogy szolgálják, amelyet ráadásul aktív - bírósági - jogvédelemmel kell hatékonnyá tenni. Ebben a változásban az európai jogharmonizáció döntő szerepet tölt be: Weber szerint látni kell, hogy elsősorban az Európai Unió, valamint az Európa Tanács joganyagai miatt a jogállamiság biztosítása európai szintűvé vált, a demokrácia és a jogállamiság egy több szinten összefonódó rendszert képez Európában. ${ }^{30}$ A probléma ezzel az, hogy - valamelyest a demokráciához hasonlóan - a jogállamiság nemcsak a jogelmélet számára sem egészen pontosan körülhatárolható fogalom, hanem lényegében egyetlen európai állam alkotmánya és alkotmánybírósága sem határoz meg a jogállamisággal kapcsolatosan egy egzakt fogalmat, noha a II. világháború, majd különösen a hidegháború óta általános elismerést nyert az európai államok közjogi gondolkodásában. Például a nemzetközi viszonylatban is nagy tekintéllyel bíró szövetségi szintű német alkotmánybíróság (német kifejezéssel: Bundesverfassungsgericht) 1977-ben egy élethossziglani szabadságvesztésről szóló ügyben úgy találta, hogy a jogállamiság alapelve megköveteli, hogy a kegyelem és minden más, a büntetések végrehajtásának felfüggesztését eredményező jogi aktus feltételrendszerét előzetesen írásba kell foglalni, azonban nem határozta meg a jogállamiság pontos fogalmát. „A jogállamiság elve egy vezéreszme, amely közvetlenül köti a törvényalkotót; (...) ez az elv az alkotmánybíróság ítéletei szerint nem foglal magában minden egyes tényállásra vonatkozóan részletekbe menően és egyértelműen meghatározható, alkotmányos jelentőséggel bíró követelményt és tilalmat; ez az alkotmányos elv további konkretizálást igényel az adott eset összes körülményeinek függvényében, amely során a jogállam és jogállamiság fundamentális elemeit egészében kell garantálni." 31

\footnotetext{
30 WEBER, 2008. 268-292.o.

31 BvL 14/76., 193.
} 
Az Európai Unióról szóló szerződés is ma már több kifejezett utalást tesz a jogállamiság intézményére, elismeri azt uniós alapértékként is az Európai Unióról szóló szerződés 2. cikkében. Az Európai Unió Bíróságának joggyakorlata szerint a jogállamiság elsődleges jelentőségű alkotmányos elv, elviekben a legkorábbi ítéleteit is úgy értelmezi, hogy azok a jogállami gondolat alappillérei, így a legalitás, a jogbiztonság, vagy az arányosság jegyében születtek. A legkorábbi ilyen ügy az 1957-ben hozott ún. Algeraitélet $^{32}$ volt, azóta a bíróság számos további olyan elvet ismert el, amelyeket ma a jogállamiság szerves részének tekint. Részben olyan eljárási garanciákról van szó, mint amilyen a jogi védelemhez, vagy a meghallgatás való jog, az iratbetekintés joga, stb. Ezek tehát az újabb európajogi értelmezések szerint már ugyancsak a jogbiztonság részét képezik, mivel ezek azok az alapvető eljárásjogi biztosítékok, amelyek képesek „megtestesíteni a jogállamiságot”. ${ }^{33}$

\section{A JOGÁLLAMISÁG EURÓPAIZÁLÓDÁSÁNAK KRITIKUS PONTJAI}

Laurent Pech szerint a jogállamiság európaizálódását az teszi lehetővé, hogy ugyan valóban vannak különbségek az Európai Unió tagállamainak alkotmányos rendszerében és jogállami struktúrájában, azonban a II. világháború óta lezajlott folyamatok azt mutatják, hogy fontos pontok és „metalelvek” mégis közösek, így nem állítható, hogy a jogállamiságról alkotott felfogásukban nincsenek közös nevezők. Pech szerint az Európai Unió jogállamisága az alapjogokhoz hasonlóan és egyfajta „ernyő” jelleggel biztosít védelmet az európai jogrend számára, mivel az Európai Unió Bírósága azt afféle értelmezési iránymutatóként használja és így további konkrét jogi normák megalkotásának alapjául szolgál. Ebből az következik, hogy az uniós jogállamiság valójában szélesebb körben kerül alkalmazásra, mint ahogy általában a nemzetállamok szintjén. Mindazonáltal Pech is elismeri, hogy problémák is jellemzik az Európai Unió jogállami programját: egyes esetekben ugyanis figyelemelterelésre és retorikai célokra használják politikai-ideológiai célok elérése érdekében. Másrészt az Európai Unió alkotmányos hiányosságait vizsgálva számos olyan pontot találhatunk, amelyet aligha lehet párhuzamba állítani a jogállamiság elvével. ${ }^{34}$

\footnotetext{
32 Európai Unió Bírósága, 1957. 56.o. Megjegyzés.: Dikene Algera és társai az Európai Szélés Acélközösség Közgyűlése ellen indított semmisségi eljárásban hozott ítélet.

33 DANWITZ, 2014. 1316.o.

34 PECH, 2009. 48.o.
} 
Pechez viszonyítva Dimitrij Kochenov átfogóbb dilemmaként azonosítja a jogállamiság és az Európai Unió kapcsolatát. Ugyan beágyazódott a köztudatba az a sokat propagált felfogás, hogy az Európai Unió jogrendszere a jogállamiság intézményén alapszik, valójában azonban a jogállamiság modern, autentikus megközelítésmódja szerint ez a kép téves Kochenov szerint. A legalapvetőbb probléma, hogy nem történik meg a törvényhatóság és a kormányzati szféra szétválasztása, a kormányzati szférát lényegében nem kötik alkotmányos szintû hatásköri korlátozások. Kochenov úgy látja, hogy az Európai Unió a jogállamiságot pusztán afféle vizsgálati eszközként alkalmazza annak érdekében, hogy biztosítsa jogrendszere autonómiáját az esetlegesen felmerülő külső és belső vitákkal szemben. Ez azonban éppen az ellenkezője a jogállamiság lényegének. Megjegyzendő ugyanakkor, hogy Kochenov jogállam-értelmezése szerint az Európai Uniónak hatékonyabb jogi eszközökkel kellene rendelkeznie az Európai Unióról szóló szerződés 2. cikkében foglalt alapértékek érvényesítése vonatkozásában is, vagyis Kochenov véleményét nem a szuverenitás védelme szempontjából fogalmazta meg. ${ }^{35}$

Hans J. Lietzmann az Európai Uniót defektes, vagy ún. hibrid demokráciának tartja, amely a jogállamiságot lényegében csak eszközként használja bizonyos politikai és ökonómiai programok megvalósítása érdekében. Lietzmann szerint valójában már az Európai Unió történelmi kiindulópontjánál olyan körülmények álltak fenn, amelyek nem egy demokratikus, sokkal inkább egy autokratikus rezsim kiformálódását indították el. Már eleve a Montánunió, az Euroatom és az Európai Gazdasági Közösség megalapítása is kifejezetten szupranacionális stratégia részét képezte. Ezek az intézmények kifejezetten a nemzetállami politikai kötöttségekkel szemben való önállósodás révén nyerték el voltaképpeni értelmüket. Lietzmann egyfajta rendszerszintű szükségszerűségként írja le, hogy az Európai Bizottság, az EU Tanácsa és különösen az Európai Unió Bírósága - a szupranacionális alkotmányosság talaján állva - a nemzeti kormányzatokkal szemben cselekszik. Lietzmann az Európai Unió jogállami programját a porosz abszolutizmus Rechtsstaat-programjával állította párhuzamba, amely valójában egyáltalán nem a demokratikus szabadság kialakulását, hanem a gazdasági és kereskedelmi szféra egységesítését célozta. Ez a „felülről jövő forradalom” közgazdasági és politikai centralizációs intézkedéssorozat volt, amelyben a német államigazgatási jog

${ }^{35}$ KochenOV, 2015. 74-96.o. 
egységesítése is fontos szerepet játszott. Lietzmann szerint azonban az Európai Unió fejlődési pályája és a XIX. századi Poroszország „modernizációs rezsimje” között nem puszta véletlenszerű teoretikai összefüggések állíthatóak fel, hanem tényleges kontinuitás. Ez azonban egyúttal az Európai Unió történelmi pályáját is döntően meghatározhatja. ${ }^{36}$

Végül a fenti álláspontokhoz tehetjük hozzá, hogy alighanem hasonlóan kritikus ponttá válhat az Európai Unió Bíróságának a jogállamiságról alkotott egyfajta expanzív jellegű értelmezési iránya is. A Bíróság az utóbbi években megerősítette, hogy a jogállamiság döntő kritériumának tartja az intézményi, elsődlegesen pedig a bírósági függetlenséget. A függetlenség kritériumrendszerét pedig az elmúlt években több jelentôs bírósági ítéletben ${ }^{37}$ ismételten hangsúlyozta, szervezeti, a bírók státuszához, feladatköréhez kapcsolódó egyéb feltételek vonatkozásában pedig tovább is mélyítette azt. Átfogóan tekintve az elvileg tagállami szinten működő nemzeti bíróságok uniós jogi kötöttségeit, így például az uniós joggal összhangban történő jogértelmezés kötelezettségét, az igazságügyi együttmúködésen belüli együttmúködési kötelezettségeket, a nemzeti bíróságok uniós „függetlenségi” kritériuma lényegében azt jelenti, hogy a gyakorlatban azok egyre inkább az uniós jogrendszer részét képezik. Ezt együtt tekintve olyan fejleményekkel, mint az uniós büntetőjogi joghatóság megerôsödése, illetôleg olyan kezdeményezések, mint az európai ügyészség hatáskörének kiterjesztése, akár a közeljövőben igen jelentős kompetencia áttolódás mehet végbe az uniós szint irányába. Ez pedig a központi hatalom kontinentális szintű koncentrációja, vagyis éppen a jogállamiság témaköre szempontjából vizsgálandó kockázati tényező lehet.

\section{KONKLÚZIÓ}

Elemzésünkben rámutattunk arra, hogy a jogállami gondolat bizonyos alapvető kiinduló pontjai már egészen az antikvitástól jelen voltak a közgondolkodásban, mégha a „klasszikusoknál” a hatalom és jog viszonyának kérdései elsősorban morális vonatkozásokkal is vetődtek fel. Magának a jogállamiság eszméjének a kibontakozása leginkább a felvilágosodáshoz köthető, noha praktikus politikai-hatalmi tényezők is szerepet játszottak a jogállami tendenciákban, különösen az angolszász „,rule

\footnotetext{
36 LIETZMANN, 2004. 19-30.o.

${ }^{37}$ C-216/18, C-64/16
} 
of law” - típusú jogállami tradíció tekintetében. A kontinentális Rechtsstaat felfogás elsődlegesen a porosz felvilágosult abszolutizmushoz köthető, amelynek keretében a porosz uralkodó - „fentről - lefelé” szervezve hatalmát - biztosított bizonyos jogi garanciákat az államhatalom működésében. Ezt a folyamatot Lietzmann lényegében tudatos centralizációként értelmezi és szoros párhuzamba állítja az Európai Unió jogállami programjával.

A hatalomról, államról és jogról való gondolkodás XIX. századi felerősödése rámutatott arra, hogy e három absztrakt fogalom ontológiai viszonyrendszere erősen feszültségteljes és tisztázatlan. Egyebek mellett Jhering és Kelsen később vitatott tanaiban is - eltérő mértékben - megjelent a jog és az erőszak összekapcsolása, felfogásuk szerint a jog a politikai hatalom eszköze. Kelsennél emiatt a jogállam formális értelmezése dominált, felfogása szerint lényegében minden állam egyúttal jogállam is, mivel az állam maga alkot egy jogrendet.

A II. világháború megrázkódtatásait követően - Jhering és Kelsen pozitivista tanaival szemben - a természetjoggal együtt a materiális jogállami felfogás erôsödött fel. Ez azt eredményezte, hogy a XXI. századra a jogállamiság fogalma kitágult és Európában az Európai Unió jogi rezsimje és az európai emberi jogi tárgyú egyezmények miatt feszült viszonyba került a nemzetállami szuverenitás kérdésével. Újabb értelmezések szerint a jogállamiság mára egy összeurópai alkotmányos alapelvé vált, amely tekintet nélkül az egyes európai államok alkotmányos tradícióira - egy európai „alkotmányközösség”, így pedig ellentmondásos módon egy kontinentális szintû hatalomkoncentráció indukálója is lehet. További vizsgálandó kérdéskör, hogy mennyiben fér ez össze az Európai Unió jelen tanulmány bevezetőjében tárgyalt Staatenverbund jogi minőségével.

\section{FELHASZNÁLT IRODALOM}

Allgemeines Landrecht FÜr die Preussischen StAaten (1794) 22. és 77. szakasz.

Aristoteles (2014): Politik. 4. Aufl. Rowohlts Ezyklopädie, Leck

Bundesverfassungsgericht in der Bundesrepublik Deutschland: LissabonUrteil. 2 BvE 2, 5/08, 2 BvR 1010, 1022, 1259/08, 182/09. 229 - 334.

Bundesverfassungsgericht in der Bundesrepublik Deutschland: Lebenslage Freiheitsstrafe, 1 BvL 14/76. 193. 
Adam CZARnota - MARTin Krygier - WojCIECH SAdurski (2005): Rethinking the Rule of Law after Communism. CEU Press, Budapest

C-7/56 és C-3-7/57 sz. ügyben hozott itélet Dineke Algera és társai az Európai Szél- és Acélközösség Közgyúlése ellen semmiség megállapítása iránt indított ügyben.

C-26/62 sz. ügy hozott ítélet a Van Gend and Loos és a holland adóhatóság között folyó ügyben és a C-6-64 sz. ügy Flaminio Costa és az E.N.E.L. között folyamatban levő eljárásban.

C-64/16. sz. ügyben hozott ítélet az Associacao Sindical dos Juízes Portugueses a Tribunal de Contas ellen indított eljárásban és a C-216/18. sz. ügyben hozott ítélet az LM ellen kibocsátott európai elfogatóparancs végrehajtása tárgyában megindult eljárásban.

CONRAD, HERMANN (1961): Rechtsstaatliche Bestrebungen im Absolutismus Preußens und Österreichs am Ende des 18. Jahrhunderts. VS Verlag für Sozialwissenschaften

DANwITZ, THOMAS VON (2014): The Rule of Law in the Recent Jurisprudence of the ECJ. In.: Fordham International Law Journal, Volume 37, Issue 5

DiCEY, ALBERT VENN (1923): Introduction to the Study of the Law of the Constitution. Macmillan, London

DilTHEY, WilHELM (1985): Zur preussischen Geschichte. Vandenhoeck \& Ruprecht, Göttingen

HAhn, ERICH: Rudolf GNEIST And the PRussian ReCHTSSTAat: 186278. In.: The Journal of Modern History. Vol. 49, No. 4.

Hallam, HenRy (1827): The Constitutional history of England from the accession of Henry VII. To the death of George II., Vo. 1. Baudry, Paris

JHERING, Rudolf VON (2008): Der Recht im Zweck. Druck und Verlag von BreitKopf und Härtel, Leipzig, 1877. Kelsen, Hans: Die reine Rechtslehre. Mohr-Siebeck, Tübingen

KochenOv, Dimitry (2015): EU Law without the Rule of Law: Is the Veneration of Autonomy Worth It? In.: Yearbook of European Law 34 (1)

MacCormick, NeIL (1984): Der Rechtsstaat und die rule of law. In.: JuristenZeitung, Mohr Siebeck GmbH, 39. Jahrgang, Nr. 2.

MACCORMICK, NeIL (1999): Questioning Sovereignity. Oxford University Press, Oxford

MOHL, ROBERT VON (1829): Das Staatsrecht des Königreiches

Württemberg. Laupp, Tübingen 
LIETZMANN, HANS J (2004).: Die Europäische Union als „defekte Demokratie?" Rechtsstaat und Pfadabhängigkeit in Europa. In.: Österreichische Zeitschrift für Politikwissenschaft

LÜBBE, HERMANN (1994): Abschied vom Superstaat: Vereinigte Staaten von Europa wird es nicht geben. LIT-Verlag, Berlin

PeCh, Laurent (2009): The Rule of Law as a Constitutional Principle of the European Union. In.: Jean Monnet Working Paper 04/09.

Rutherford, Samuel (2014): Rex Lex, or The Law and The Prince. Portage Publications, Colorado

STAHL, FRIEDRICH JULIUS (1878): Rechts- und Staatslehre auf der Grundlage christlicher Weltanschauung. Zweite Abteilung: Die Staatslehre und die Principien des Staatsrechts, J.C.B. Mohr, Tübingen, 5., unveränd. Auflage 1878.

SusemiHl, Franz (1862): Platón: Nomoi (Die Gesetze). Platon's Werke, Stuttgart

Svartz, N.P. (2010): Thomas Aquinas: On Law, Tyranny and Resistance. In.: Acta Theologica, 2010/30.

TOURI, K (2013):: The Common Core of the Rule of Law and the Rechtsstaat, Law of Ukraine, Legal Journal, Vol. 2013 (4)

Villata, Gigliola die Renzo (2016): Beccaria und die Anderen. LIT Verlag, Berlin

VON DER PFordten, Dietmar (2014): On the Foundations of the Rule of Law and the Principle of the Legal State/Rechtsstaat. In.: SilkenatHickey-Barenboim: The Legal Doctrines of the Rule of Law and the Legal State. Springer, Switzerland

WeBER, AlBRECHT (2008): Rechtsstaatsprinzip als gemeineuropäisches Verfassungsprinzip. In.: Zeitschrift für Öffentliches Recht. DOI azonosító: https://doi.org/10.1007/s00708-008-0210-0 